\title{
Short communication: Multi-component interactions causing solidification during industrial-scale manufacture of pre-crystallized acid whey powders
}

\author{
Kamil P. Drapala, ${ }^{*} \dagger$ Kevin M. Murphy, $¥ \S$ Quang Tri Ho, $¥ \S$ Shane V. Crowley, ${ }^{*}$ Shane Mulcahy,\# \\ Noel A. McCarthy, $\ddagger \S$ and James A. O’Mahony* $\dagger^{1}$ \\ *School of Food and Nutritional Sciences, and \\ †Dairy Processing Technology Centre, University College Cork, Cork, Ireland T12 K8AF \\ ¥Food Chemistry and Technology Department, and \\ §Dairy Processing Technology Centre, Teagasc Food Research Centre, Moorepark, Fermoy, Co. Cork, Ireland P61 C996 \\ \#Arrabawn Co-Operative Society Ltd., Nenagh, Co. Tipperary, Ireland E45 XP86
}

\begin{abstract}
Acid whey (AW) is the liquid co-product arising from acid-induced precipitation of casein from skim milk. Further processing of AW is often challenging due to its high mineral content, which can promote aggregation of whey proteins, which contributes to high viscosity of the liquid concentrate during subsequent lactose crystallization and drying steps. This study focuses on mineral precipitation, protein aggregation, and lactose crystallization in liquid AW concentrates ( $\sim 55 \%$ total solids), and on the microstructure of the final powders from 2 independent industrial-scale trials. These AW concentrates were observed to solidify either during processing or during storage $(24 \mathrm{~h})$ of pre-crystallized concentrate. The more rapid solidification in the former was associated with a greater extent of lactose crystallization and a higher ash-to-protein ratio in that concentrate. Confocal laser scanning microscopy analysis indicated the presence of a loose network of protein aggregates $(\leq 10 \mu \mathrm{m})$ and lactose crystals $(100-300 \mu \mathrm{m})$ distributed throughout the solidified AW concentrate. Mineral-based precipitate was also evident, using scanning electron microscopy, at the surface of AW powder particles, indicating the formation of insoluble calcium phosphate during processing. These results provide new information on the composition- and process-dependent physicochemical changes that are useful in designing and optimizing processes for AW.
\end{abstract}

Key words: acid whey, calcium phosphate, lactose, powder, microstructure

Received March 27, 2018.

Accepted August 2, 2018.

${ }^{1}$ Corresponding author: sa.omahony@ucc.ie

\section{Short Communication}

The increased global demand for casein-based ingredients and products has led to the need to process higher volumes of their problematic by-product acid whey (AW). Several billion liters of AW are produced every year by dairy processors globally (Chandrapala et al., 2015). Acid whey originates from the manufacture of cream cheese and strained yogurt products (casein gelation with lactic acid from starter culture) or acid casein powders (e.g., precipitation using hydrochloric acid and by lactic fermentation). The latter process results in most of the whey protein, $\mathrm{Ca}, \mathrm{P}$, and lactose transferring to the AW. The levels of $\mathrm{Ca}$ and $\mathrm{P}$ in $\mathrm{AW}$, expressed on a DM basis, are higher than those of milk by 75 and $45 \%$, respectively. This is due to the shift in the Ca equilibria from the insoluble (casein-bound calcium phosphate) to the soluble (serum-based) state during acidification of milk (Ozcan et al., 2011). Acid whey can be fractionated using UF to yield a stream enriched in whey proteins and a permeate stream composed mostly of lactose, minerals, and water. However, due to the high volumes of AW available commercially, it is often converted directly into powders (i.e., using evaporation, pre-crystallization, and spray drying) without any additional fractionation steps, due to equipment availability and capacity constraints. Challenges with processing of AW are largely due to its high levels of minerals, heat-labile whey proteins, lactose, and lactic acid, making it challenging to spray dry (Chandrapala et al., 2015).

On an industrial scale, AW is typically neutralized from $\mathrm{pH} 4.5$ to 7.0 (e.g., by addition of potassium hydroxide), subsequently concentrated using nanofiltration from $\sim 5$ to $\geq 20 \%$ TS, followed by vacuum evaporation from $\sim 20$ to $>50 \%$ TS and slowly cooled (i.e., from $\sim 60$ to $\sim 12^{\circ} \mathrm{C}$ ) under agitation in specialized lactose crystallization tanks before spray drying. A high degree of component inter-reactivity is possible, and indeed oc- 
curs, during processing due to precipitation of calcium phosphate $(\mathbf{C a P})$, aggregation of protein, and crystallization of lactose, which may present challenges during the manufacturing of AW. It is necessary to better understand the interactions between the components of AW systems and the effects processing parameters have on the interactions between these components. This will allow improvements in processing performance of AW and facilitate further valorization of this dairy stream.

Significant advancements in knowledge regarding the processing of AW generated from the lactic acidinduced precipitation of casein have been recently made by Chandrapala and Vasiljevic (2017) and Nishanthi et al. (2017a,b,c). Nishanthi et al. (2017a,b) compared concentrates and corresponding powders obtained from native, acid (from Greek yogurt manufacture), sweet, and salty whey streams for their secondary protein structures, protein interactions, and microstructure. Bedas et al. (2017) investigated improvement in the drying performance (i.e., focused on product yield and powder hygroscopicity) of lactic AW by partial removal of monovalent ions and lactic acid using nanofiltration. Mimouni et al. (2007) reported on the effect of formation of filamentous calcium lactate crystals on the viscosity of AW concentrates, where thickening thereof was observed during the lactose crystallization step, regardless of the presence or absence of whey protein. Despite the absence of calcium lactate in AW arising from mineral acid casein manufacture, pre-crystallized concentrates produced from this stream are not free from challenges with thickening. These challenges are likely linked to the changes in the protein (aggregation), mineral (precipitation), and lactose (crystallization) phases of AW and their potential inter-reactivity. Greater knowledge of these changes and their interactions in this system can provide important fundamental information of assistance in alleviating processing challenges for AW.
The AW powders in this study, with protein content of 8 to $12 \%$ (wt/wt), are of particular interest due to their high ash-to-protein ratio of $1: 1$, which contributes to processing challenges, such as high viscosity and impaired flow of the concentrate. In this study, 2 sets of paired concentrate and powder samples (i.e., pre-crystallized spray dryer feed and final spray-dried powders, respectively) from 2 independent plant trials (Arrabawn Co-Operative Society Ltd., Nenagh, Co. Tipperary, Ireland) were selected as examples of different AW processing scenarios; one, optimal AW $\left(\mathbf{A W}_{\mathbf{O p t}}\right)$ displayed little challenges during its processing, and the other, suboptimal AW $\left(\mathbf{A W}_{\text {Sub }}\right)$ solidified during the manufacturing process, resulting in blockage of the spray dryer feed line (Figure 1). The 2 sets of samples were studied to provide, for the first time, an insight into the reasons for the solidification (i.e., formation of a visibly continuous, nonflowing, solid mass) of AW concentrate, with a particular focus on protein-mineral interactions, precipitation of $\mathrm{CaP}$, and lactose crystallization. This study aims to advance the understanding of the mechanisms driving physicochemical changes during manufacture of AW from an acid casein powder process and facilitate more efficient processing of this dairy stream.

Acid whey from the manufacture of acid casein powder (i.e., acidification with hydrochloric acid) was pre-concentrated using reverse osmosis (from $\sim 5$ to $22 \%$ TS), followed by neutralization (from $\mathrm{pH} 4.5$ to 7.0) with potassium hydroxide, and evaporated using falling-film vacuum evaporation to $\sim 55 \% \mathrm{TS}$. The concentrates were subsequently cooled from $\sim 60$ to $12^{\circ} \mathrm{C}$ with continuous agitation $(\sim 8 \mathrm{~h})$ to allow crystallization of lactose before spray drying, using rotary wheel atomization. Two batches of crystallized AW concentrates ( $\sim 55 \%$ TS content) and resultant spray-dried powders $(\sim 9.0 \%$ protein, $9.0 \%$ ash, $80 \%$ lactose, $0.5 \%$

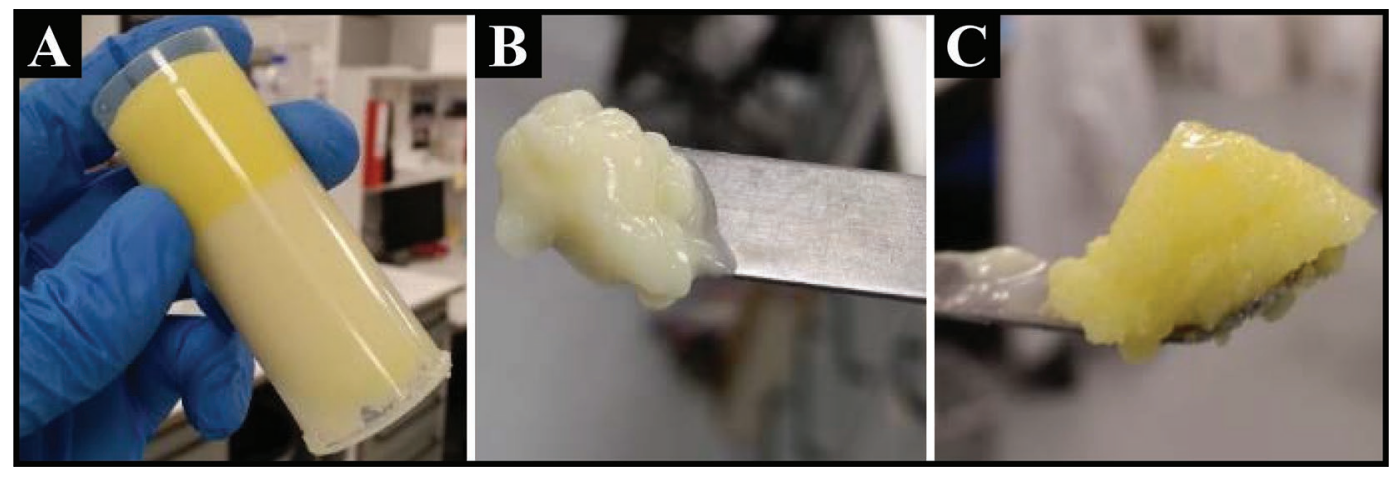

Figure 1. Images of solidified optimal acid whey concentrate sample $\sim 24 \mathrm{~h}$ after sample collection. Block (A) represents the whole sample with visible phase separation into (B) lower density continuous phase and (C) higher density sedimented phase. The suboptimal acid whey concentrate sample displayed a homogeneous combination of the 2 phases (i.e., B and C), where the solidification of the system occurred quickly enough to prevent any noticeable phase separation. Color version available online. 
fat, and $1.5 \%$ moisture) were produced in 2 independent industrial-scale trials. The 2 powder samples were vacuum packed in heat-sealed polyamide/polyethylene bags (Fispak Ltd., Dublin, Ireland) with a moisture permeability of $2.6 \mathrm{~g}^{-2} \cdot \mathrm{d}^{-1}$. The powders were stored in the dark at ambient conditions (i.e., $\sim 20^{\circ} \mathrm{C}$ ) until further analyses within 2 wk of spray drying. The 2 AW batches (manufactured 2 wk apart) were selected for this study based on their divergent behavior during the manufacturing process and on the differences in the physicochemical properties of the final powders. One of the batches displayed challenges with rheological behavior, manifested by solidification of the contents of the spray dryer feed line $\left(\sim 14^{\circ} \mathrm{C}\right.$; spray-dried without preheating) during production. Conversely, the other batch of AW did not display this behavior and production progressed without solidification of the concentrate. The $2 \mathrm{AW}$ batches are referred to as $\mathrm{AW}_{\mathrm{Sub}}$ and $\mathrm{AW}_{\text {Opt }}$, respectively.

Photographs of the concentrate samples (Figure 1) were taken using a camera (Samsung Galaxy S5, Samsung Group, Seoul, South Korea). Confocal laser scanning microscopy (Olympus FV1000, Olympus Corporation, Tokyo, Japan) was used to visualize the protein network (labeled with $0.1 \%$, wt/vol, Fast Green FCF dye, Sigma-Aldrich, Wicklow, Ireland) in the solidified $\mathrm{AW}_{\text {Sub }}$ concentrate sample as detailed by Drapala et al. (2015). Furthermore, to assess the properties of the AW powders obtained from the 2 batches, particle size distribution (PSD) of the powders was measured using a laser light diffraction unit (Mastersizer 3000, Malvern
Instruments Ltd., Worcestershire, UK) as detailed by Drapala et al. (2017). Scanning electron microscopy (JSM- 5510, Jeol Ltd., Tokyo, Japan) was used to determine the microstructure of the AW powders as detailed by Drapala et al. (2017). Representative micrographs were taken at $5 \mathrm{kV}$ at $50 \times, 350 \times$, and $4,000 \times$ magnifications. Determination of elemental composition of surfaces of powder particles was conducted by scanning electron microscopy (S-3000N, Hitachi, Tokyo, Japan) coupled with energy dispersive X-ray spectroscopy (EDX) and INCA software (Oxford Instruments, Abingdon, UK); the scanning electron microscopy was operated at $20 \mathrm{kV}$. The elemental composition of bright and dark regions on the surface of particles in both powders was determined by focusing on at least 4 individual regions (i.e., bright and dark) for each powder particle.

Compositional analysis of the 2 samples showed lower TS (\%), higher mineral (\% of dry mass), and similar protein (\% of dry mass) contents in the $\mathrm{AW}_{\text {Sub }}$ sample, compared with the $\mathrm{AW}_{\text {Opt }}$ sample (i.e., 51.9, 10.7, 8.7, and $54.7,9.5,8.8$, respectively). Importantly, the 2 AW samples differed in ash:protein ratio, which was higher in the $\mathrm{AW}_{\text {Sub }}$ sample, compared with the $\mathrm{AW}_{\text {Opt }}$ sample (i.e., 1.22 and 1.09, respectively). Tomahawkshaped $\alpha$-lactose monohydrate crystals (Parimaladevi and Srinivasan, 2014; 100-300 $\mu \mathrm{m}$ ) distributed within a continuous phase were observed in the $\mathrm{AW}_{\text {Sub }}$ concentrate using confocal laser scanning microscopy analysis (Figure 2A). This continuous phase consisted of numerous, relatively small $(\leq 10 \mu \mathrm{m})$, and irregularly shaped

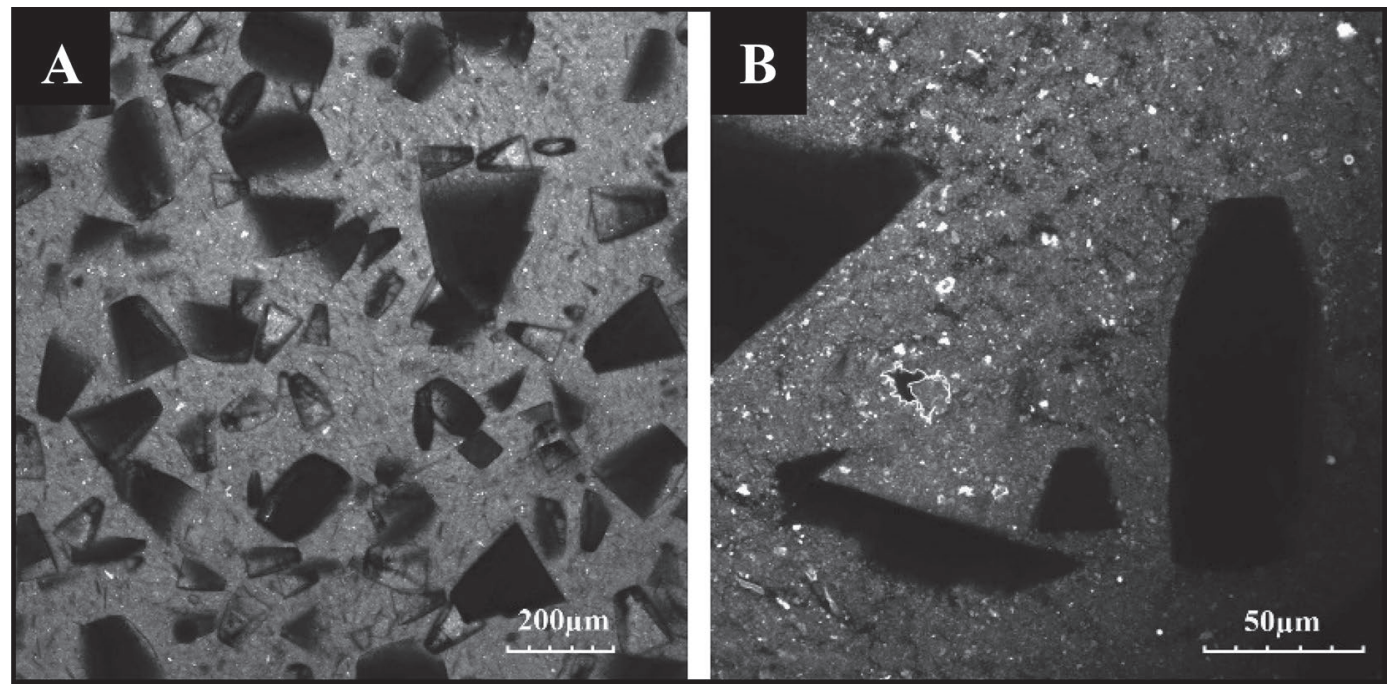

Figure 2. Confocal laser scanning microscopy images of suboptimal acid whey concentrate sample $\sim 24 \mathrm{~h}$ after sample collection at (A) $10 \times$ and (B) $60 \times$ magnifications. Protein (white) was selectively labeled with Fast Green (Sigma-Aldrich, Wicklow, Ireland) fluorescent dye. The higher intensity of the signal (i.e., white regions) indicates higher density protein clusters (i.e., aggregates of $\leq 10 \mu \mathrm{m}$ ). Black trapezoidal-shaped regions indicate localization of lactose crystals $(100-300 \mu \mathrm{m})$. 
protein aggregates distributed in a continuous phase (Figure 2B).

We observed noteworthy differences in the microstructure of the 2 AW powders, as visualized using scanning electron microscopy, where a range of magnifications were selected to study the morphology (i.e., $50 \times$ and $350 \times$ ) and surface topography (i.e., $350 \times$ and $4,000 \times$ ) of powders (Figure 3 ). Two classes of particles were present in both powders, tomahawk-shaped particles corresponding to lactose crystals (i.e., solid during atomization), and spherical particles corresponding to the continuous liquid phase (i.e., composed of water, noncrystalline lactose, protein, and minerals) forming drops on atomization (Figure 3 ). The $\mathrm{AW}_{\text {Sub }}$ powder appeared to have a higher number of lactose crystals, compared with the $\mathrm{AW}_{\mathrm{Opt}}$ powder sample, with the lactose crystals appearing to be generally larger in the $\mathrm{AW}_{\text {Sub }}$ powder, compared with the $\mathrm{AW}_{\text {Opt }}$ powder. Spherical particles were more numerous in the $\mathrm{AW}_{\mathrm{Opt}}$ sample, and they also appeared to be smaller and more round compared with the larger and more elongated particles in the $\mathrm{AW}_{\text {Sub }}$ powder (Figure 3, 350×). We also observed differences in the surface topography of powders; bright crystal-like structures were observed on the surface of virtually all powder particles in the $\mathrm{AW}_{\text {Sub }}$ sample (Figure 3 ). We also observed these features, but to a much lower frequency, on the surface of some particles in the $\mathrm{AW}_{\text {Opt }}$ powder, which could be related to the lower ash-to-protein ratio in that sample. Nucleation and growth of CaP crystals was previously reported to be retarded in the presence of whey protein (Tsuge et al., 2002), which could provide some explanation for the lower occurrence of such crystals in the $\mathrm{AW}_{\text {Opt }}$ powder. During scanning electron microscopy analysis, intensity of the detected signal is related to backscattering of primary (high-energy) electrons, which increases with increasing average atomic number of the elements composing the sample and results in a bright appearance for such high-energy regions on the sample surface (Suga et al., 2014). The distinctive bright appearance of the crystal-like structures in the AW samples indicated localized presence of elements from inorganic salts with higher atomic number (e.g., $\left.\mathrm{Ca}^{20}, \mathrm{P}^{15}\right)$, compared with the darker regions on the surface of the sample (e.g., $\mathrm{C}^{6}, \mathrm{~N}^{7}$, and $\mathrm{O}^{8}$ : major elements in dairy macronutrients). We associated the presence of these structures with formation of $\mathrm{CaP}$ crystals, a phenomenon commonly encountered in alkalized AW due to the high content of both $\mathrm{Ca}$ and $\mathrm{P}$ and the $\mathrm{pH}$ (6.6-7.0) being favorable for CaP precipitation, in the manufacturing process (Tanguy et al., 2016). Most of the CaP crystals in our study were likely at an early nucleation stage (i.e., dicalcium phosphate dihydrate, $\mathrm{CaHPO}_{4} \cdot 2 \mathrm{H}_{2} \mathrm{O}$ ), where the crystals adopt the form of thin sheets, as described by Li et al. (2016). These precursors can re-crystallize further to form microspheres and undergo additional growth through an Ostwald ripening-type mechanism ( $\mathrm{Li}$ et al., 2016), further increasing their potential for interactions with protein and promoting association into a protein-CaP network (Tercinier et al., 2013); we also observed such advanced $\mathrm{CaP}$ microsphere-type structures in the $\mathrm{AW}_{\text {Sub }}$ powder (micrographs not included). Chandrapala et al. (2016) discussed the significant effect the presence of $\mathrm{CaP}$ has on the crystallization behavior of lactose, where these mineral crystals can deposit onto and be incorporated into the lactose crystals, leading to a second lactose nucleation step, effectively influencing the size distribution, geometry, and crystallization behavior of lactose crystals. Analysis of elemental surface composition of the bright and dark regions on the surface of powder particles in $\mathrm{AW}_{\text {Opt }}$ and $\mathrm{AW}_{\text {Sub }}$ powder samples using EDX revealed higher levels of $\mathrm{Ca}$ and $\mathrm{P}$, but also $\mathrm{K}$ and $\mathrm{Cl}$, in the bright regions on the surface of particles, compared with dark regions, in both powders. The average levels of $\mathrm{Ca}$ at the bright regions on the surface of the $\mathrm{AW}_{\mathrm{Opt}}$ and $\mathrm{AW}_{\text {Sub }}$ powders were 3.17 and $3.98 \%$, respectively, whereas $\mathrm{Ca}$ levels at the dark regions on these powders were 1.59 and $1.95 \%$, respectively. Similarly, the levels of $\mathrm{P}, \mathrm{K}$, and $\mathrm{Cl}$ were also higher within the bright regions, compared with the dark regions on the surfaces of the powders (i.e., bright $\mathrm{AW}_{\text {Opt }}$ and $\mathrm{AW}_{\mathrm{Sub}}: P=2.41$ and $2.31 \%, \mathrm{~K}=4.61$ and $8.12 \%, \mathrm{Cl}$ $=3.32$ and $5.91 \%$; dark $\mathrm{AW}_{\mathrm{Opt}}$ and $\mathrm{AW}_{\mathrm{Sub}}: P=1.05$ and $1.18 \%, \mathrm{~K}=2.63$ and $3.08 \%, \mathrm{Cl}=2.04$ and $2.27 \%$ ).

In agreement with the scanning electron microscopy results, we observed differences in the PSD between the $\mathrm{AW}_{\text {Opt }}$ and $\mathrm{AW}_{\text {Sub }}$ powders (Figure 4). Overall, the particles in the $\mathrm{AW}_{\text {Sub }}$ powder were larger than those in the $\mathrm{AW}_{\text {Opt }}$ powder, as indicated by differences in the mean particle diameter $\left(\mathrm{D}_{4,3} ; 215\right.$ and $113 \mu \mathrm{m}$, respectively). In addition, differences in the 10 and $90 \%$ quantiles of size distribution $\left(\mathrm{D}_{\mathrm{v}, 0.1}\right.$ and $\mathrm{D}_{\mathrm{v}, 0.9}$, respectively) between the 2 powders (Figure 4) indicated differences in the ratios of the 2 classes of particle population (i.e., small spheres and large tomahawks) in each of the powders and to differences in size within these classes (Figure 4). Large tomahawk-shaped particles (100-330 $\mu \mathrm{m})$, corresponding to lactose crystals, appeared to be generally bigger and more numerous in the $\mathrm{AW}_{\text {Sub }}$ powder, indicating more extensive lactose crystallization (i.e., before spray drying) in that sample, compared with the $\mathrm{AW}_{\text {Opt }}$ powder. Conversely, a lower extent of lactose crystallization was evident in the $\mathrm{AW}_{\text {Opt }}$ powder, evidenced by the presence of smaller and less numerous lactose crystals (Figure 3, 50×), which resulted in a higher proportion of noncrystalline lactose being present in the liquid component of the concentrate feed 

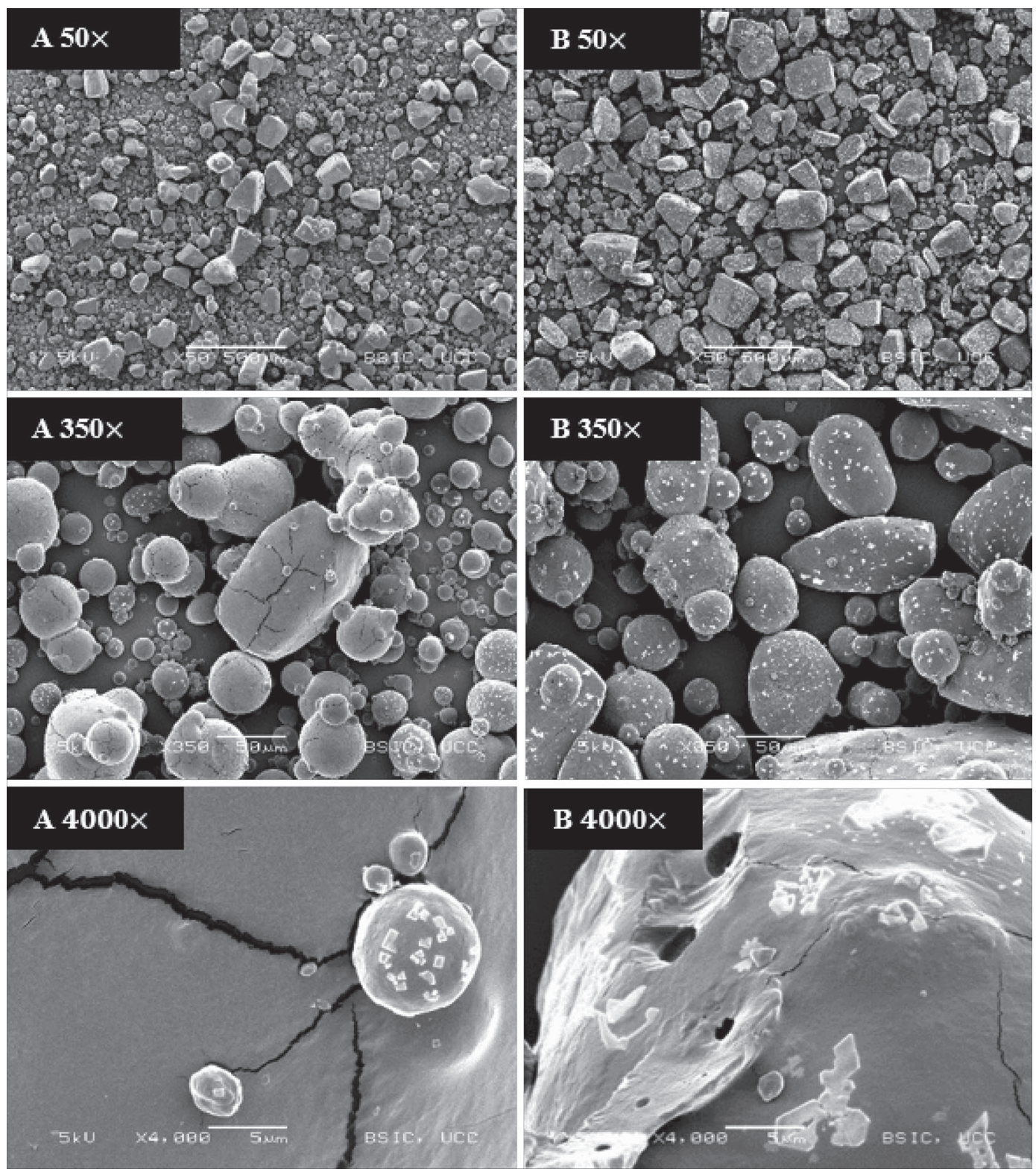

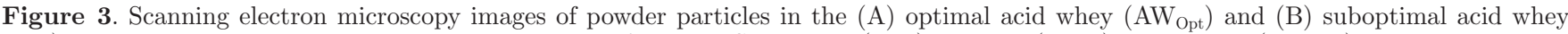
$\left(\mathrm{AW}_{\mathrm{Sub}}\right)$ powder samples at $50 \times, 350 \times$, and 4,000× magnifications. Scale bars: $(50 \times) 500 \mu \mathrm{m},(350 \times) 50 \mu \mathrm{m}$, and $(4,000 \times) 5 \mu \mathrm{m}$.

to the spray dryer. This led to a greater proportion of spherical particles in the $\mathrm{AW}_{\text {Opt }}$ powder (Figure 3 , $50 \times$, Figure 4) and probably a higher proportion of amorphous lactose in the resultant powder, compared with the $\mathrm{AW}_{\text {Sub }}$.

Results presented in our study outline several changes in the multicomponent AW concentrate, which were either mediated by direct interventions (i.e., lactose crystallization) or progressed spontaneously (e.g., mineral precipitation and concentrate solidification), where these changes took place during the manufacturing process. Higher ash-to-protein ratio and the greater extent of lactose crystallization in the $\mathrm{AW}_{\mathrm{Sub}}$ concentrate, compared with $\mathrm{AW}_{\text {Opt }}$, were identified as the main reasons for extensive thickening of the concentrate, to the point of solidification of the spray dryer feed material. These changes had concomitant effects on the PSD and morphology of the final powders. With the progression of lactose crystallization, the amount of noncrystalline lactose in the concentrate feed decreases, leading to increased contact area between other components of the feed, namely whey proteins and minerals. Electrostatic interactions between negatively charged carboxyl groups of protein and positively charged $\mathrm{Ca}$ 


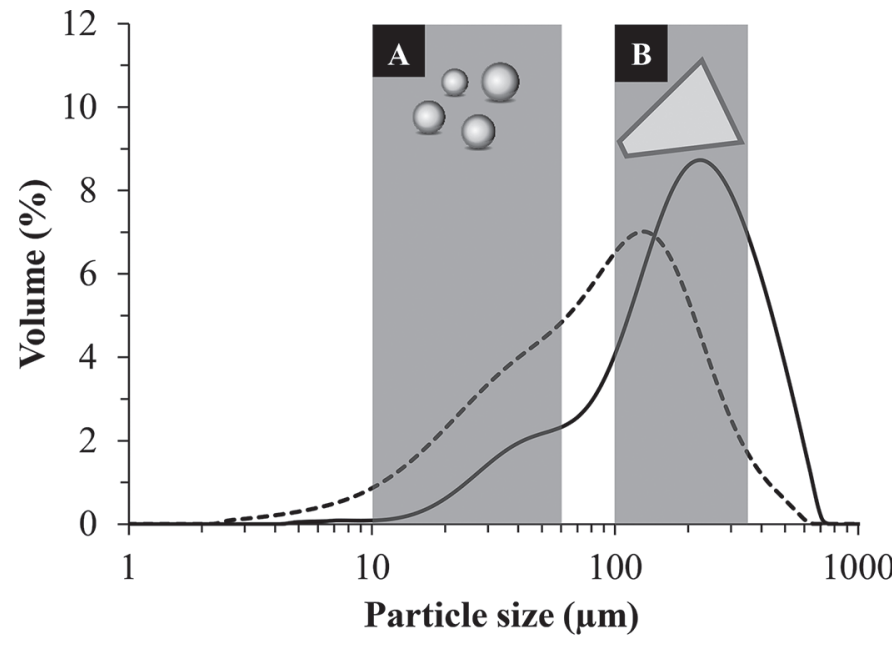

\begin{tabular}{lll}
\hline Size distribution data & $\mathbf{A W}_{\mathbf{O p t}}$ & $\mathbf{A W}_{\text {Sub }}$ \\
\hline Fraction $\mathrm{A}(10-60 \mu \mathrm{m})^{*}$ & $39.5 \%$ & $14.8 \%$ \\
Fraction B $(100-330 \mu \mathrm{m})^{*}$ & $43.2 \%$ & $60.6 \%$ \\
$\mathrm{D}_{4,3}(\mu \mathrm{m})$ & 113 & 215 \\
$\mathrm{D}_{\mathrm{v}, 0.1}(\mu \mathrm{m})$ & 20.0 & 48.8 \\
$\mathrm{D}_{\mathrm{v}, 0.9}(\mu \mathrm{m})$ & 238 & 417 \\
\hline
\end{tabular}

Figure 4. Particle size distribution of optimal (dashed line) and suboptimal (solid line) acid whey powders $\left(\mathrm{AW}_{\text {Opt }}\right.$ and $\mathrm{AW}_{\mathrm{Sub}}$, respectively). Regions dominated either by (A) spherical- or (B) trapezoidal-shaped particles are identified with the corresponding size ranges and $\left(^{*}\right)$ volume-based proportions of each of these fractions in both powders. Parameters $\mathrm{D}_{4,3}, \mathrm{D}_{\mathrm{v}, 0.1}$, and $\mathrm{D}_{\mathrm{v}, 0.9}$ represent the volume mean diameter and particle size in the 10 and $90 \%$ quantile of the distribution, respectively.

ions promote formation of a protein-mineral network; Tercinier et al. (2017) reported that whey proteins ( $\beta$ LG and $\alpha-\mathrm{LA}$ ) associated weakly with hydroxyapatite $\left[\mathrm{Ca}_{5}\left(\mathrm{PO}_{4}\right)_{3}\right]$, mainly through electrostatic forces, and this association was further promoted by a high ionic strength environment. Kharlamova et al. (2017) showed that upon denaturation and aggregation of whey protein the number of $\mathrm{Ca}^{2+}$ binding sites, per protein unit, increased by $50 \%$; they associated formation of weak gels to the attractive electrostatic interactions between aggregated whey protein and Ca. Calcium phosphate can participate in molecular interactions with whey proteins, leading to network formation and aggregation of protein, especially under conditions of $\mathrm{pH}$ and temperature that are typical of $\mathrm{AW}$ processes (Chandrapala et al., 2015). In addition, increasing number of large solid particles (i.e., lactose crystals) and uptake of water for lactose crystallization $(\sim 5 \%$ of the total mass of $\alpha$-lactose monohydrate crystal is water; Mimouni et al., 2005) strongly influence the flow properties (viscosity) of the AW concentrate. Different rheological properties of the $2 \mathrm{AW}$ concentrates studied by us in this work were manifested by different rates of in-container solidification (i.e., before or after lactose sedimentation), where in the $\mathrm{AW}_{\text {Opt }}$ concentrate lactose crystals sedimented before solidification, whereas the $\mathrm{AW}_{\text {Sub }}$ concentrate solidified more quickly, preventing rapid sedimentation of lactose crystals (Figure 1). Differences in viscosity between the 2 concentrate feeds to the dryer (i.e., $\mathrm{AW}_{\mathrm{Opt}}$ and $\mathrm{AW}_{\mathrm{Sub}}$ ) influenced the shape of particles in the resultant powders. The spherical powder particles (i.e., particles formed from liquid concentrate; Figure $3,350 \times$ ) in the $\mathrm{AW}_{\text {Opt }}$ powder were smaller and more round, compared with the larger and more elongated particles in the $\mathrm{AW}_{\text {Sub }}$ powder. Lower concentrate viscosities are known to produce smaller droplets during atomization and smaller final powder particles; higher concentrate viscosity has also been shown to result in powder particles with elongated shapes, especially during spray drying using wheel atomization systems (Pisecky, 2012).

Our study demonstrated, for the first time, the complex interplay between lactose crystallization, mineral precipitation, and the potential role of whey protein-Ca interactions on the processing behavior of liquid AW concentrate, and the physicochemical properties of resultant powders. This work identified specific areas for further research: (1) controlling the precipitation of $\mathrm{CaP}$ by manipulation of $\mathrm{pH}$ and temperature, (2) mineral phase changes with whey protein, and (3) the effect of lactose crystallization on rheological properties of AW concentrate. Our research also highlights new opportunities for alternative processing approaches for AW, such as its fractionation into higher value products (e.g., milk minerals, heat-stable whey protein powders, and lactose), while also providing process stability.

\section{ACKNOWLEDGMENTS}

The authors acknowledge the Dairy Processing Technology Centre, an Enterprise Ireland initiative, for financial support and permission to publish this work. This work was supported by the Irish State through funding from the Technology Centres Programme (Grant Number TC/2014/0016). The authors are grateful for the help of Joe Tobin at Glantreo Ltd., Cork, Ireland for EDX analysis of the powders.

\section{REFERENCES}

Bedas, M., G. Tanguy, A. Dolivet, S. Mejean, F. Gaucheron, G. Garric, G. Senard, R. Jeantet, and P. Schuck. 2017. Nanofiltration 
of lactic acid whey prior to spray drying: Scaling up to a semiindustrial scale. Lebensm. Wiss. Technol. 79:355-360. https://doi .org/10.1016/j.lwt.2017.01.061.

Chandrapala, J., M. C. Duke, S. R. Gray, B. Zisu, M. Weeks, M. Palmer, and T. Vasiljevic. 2015. Properties of acid whey as a function of $\mathrm{pH}$ and temperature. J. Dairy Sci. 98:4352-4363. https:// doi.org/10.3168/jds.2015-9435.

Chandrapala, J., and T. Vasiljevic. 2017. Properties of spray dried lactose powders influenced by presence of lactic acid and calcium. J. Food Eng. 198:63-71. https://doi.org/10.1016/j.jfoodeng.2016 .11 .017 .

Chandrapala, J., R. Wijayasinghe, and T. Vasiljevic. 2016. Lactose crystallization as affected by presence of lactic acid and calcium in model lactose systems. J. Food Eng. 178:181-189. https://doi.org/ 10.1016/j.jfoodeng.2016.01.019.

Drapala, K. P., M. A. Auty, D. M. Mulvihill, and J. A. O'Mahony. 2015. Influence of lecithin on the processing stability of model whey protein hydrolysate-based infant formula emulsions. Int. J. Dairy Technol. 68:322-333. https://doi.org/10.1111/1471-0307 .12256.

Drapala, K. P., M. A. Auty, D. M. Mulvihill, and J. A. O'Mahony. 2017. Influence of emulsifier type on the spray-drying properties of model infant formula emulsions. Food Hydrocoll. 69:56-66. https:/ /doi.org/10.1016/j.jfoodeng.2016.11.017.

Kharlamova, A., T. Nicolai, and C. Chassenieux. 2017. Calcium-induced gelation of whey protein aggregates: Kinetics, structure and rheological properties. Food Hydrocoll. 79:145-157. https://doi .org/10.1016/j.foodhyd.2017.11.049.

Li, R., Y. Cai, Y. Yang, S. Fang, X. Su, Y. Sun, and J. Yao. 2016. Dimensionally and morphologically controlled growth of calcium phosphate crystals by an organic-free hydrothermal process. Ceram. Int. 42:17387-17397. https://doi.org/10.1016/j.ceramint 2016.08.038.

Mimouni, A., S. Bouhallab, M. H. Famelart, D. Naegele, and P. Schuck. 2007. The formation of calcium lactate crystals is responsible for concentrated acid whey thickening. J. Dairy Sci. 90:57-65. https://doi.org/10.3168/jds.S0022-0302(07)72608-5.

Mimouni, A., P. Schuck, and S. Bouhallab. 2005. Kinetics of lactose crystallization and crystal size as monitored by refractometry and laser light scattering: Effect of proteins. Lait 85:253-260. https:// doi.org/10.1051/lait:2005015.

Nishanthi, M., J. Chandrapala, and T. Vasiljevic. 2017a. Properties of whey protein concentrate powders obtained by spray drying of sweet, salty and acid whey under varying storage conditions. J. Food Eng. 214:137-146. https://doi.org/10.1016/j.jfoodeng.2017 .06 .032 .
Nishanthi, M., J. Chandrapala, and T. Vasiljevic. 2017b. Compositional and structural properties of whey proteins of sweet, acid and salty whey concentrates and their respective spray dried powders. Int. Dairy J. 74:49-56. https://doi.org/10.1016/j.idairyj.2017.01 .002 .

Nishanthi, M., T. Vasiljevic, and J. Chandrapala. 2017c. Properties of whey proteins obtained from different whey streams. Int. Dairy J. 66:76-83. https://doi.org/10.1016/j.idairyj.2016.11.009.

Ozcan, T. D. Horne, and J. A. Lucey. 2011. Effect of increasing the colloidal calcium phosphate of milk on the texture and microstructure of yogurt. J. Dairy Sci. 94:5278-5288. https://doi.org/ 10.3168/jds.2010-3932

Parimaladevi, P., and K. Srinivasan. 2014. Influence of supersaturation level on the morphology of $\alpha$-lactose monohydrate crystals. Int. Dairy J. 39:301-311. https://doi.org/10.1016/j.idairyj.2014.08 007.

Pisecky, J. 2012. Achieving product properties. Pages 163-196 in Handbook of Milk Powder Manufacture. V. Westergaard and E. Refstrup, ed. GEA Process Engineering A/S.

Suga, M., S. Asahina, Y. Sakuda, H. Kazumori, H. Nishiyama, T. Nokuo, V. Alfredsson, T. Kjellman, S. M. Stevens, H. S. Chod, M. Chod, L. Hane, S. Chee, M. W. Anderson, F. Schüth, H. Dengh, O. M. Yaghi, Z. Liu, H. Y. Jeong, A. Stein, K. Sakamotom, R. Ryoon, and O. Terasaki. 2014. Recent progress in scanning electron microscopy for the characterization of fine structural details of nano materials. Prog. Solid State Chem. 42:1-21. https://doi .org/10.1016/j.progsolidstchem.2014.02.001.

Tanguy, G., F. Siddique, E. Beaucher, A. C. Santellani, P. Schuck, and F. Gaucheron. 2016. Calcium phosphate precipitation during concentration by vacuum evaporation of milk ultrafiltrate and microfiltrate. Lebensm. Wiss. Technol. 69:554-562. https://doi.org/ 10.1016/j.lwt.2016.02.023

Tercinier, L., A. Ye, S. Anema, A. Singh, and H. Singh. 2013. Adsorption of milk proteins on to calcium phosphate particles. J. Colloid Interface Sci. 394:458-466. https://doi.org/10.1016/j.jcis.2012.11 .058 .

Tercinier, L., A. Ye, S. Anema, A. Singh, and H. Singh. 2017. Characterisation of milk protein adsorption onto hydroxyapatite. Int. Dairy J. 66:27-33. https://doi.org/10.1016/j.idairyj.2016.11.005.

Tsuge, H., Y. Tanaka, S. E. I. Yoshizawa, and T. Kuraishi. 2002 Reactive crystallization behaviour of calcium phosphate with and without whey protein addition. Trans IChemE. 80:105-110. https: //doi.org/10.1205/026387602753393277. 